Inovasi Pembelajaran PAI Melalui Kegiatan Ekstrakurikuler...

\title{
INOVASI PEMBELAJARAN PENDIDIKAN AGAMA ISLAM MELALUI KEGIATAN EKTRAKURIKULER DI SMP RAUDATUT THOLABAH JENGGAWAH JEMBER
}

\author{
Mursalim \\ Prodi Pendidikan Agama Islam Fakultas Tarbiyah \\ Dan Ilmu Keguruan IAIN Jember \\ salimabuya@gmail.com \\ Hatta \\ Prodi Pendidikan Agama Islam Fakultas Tarbiyah \\ Dan Ilmu Keguruan IAIN Jember \\ hattaalsurkief@gmail.com
}

\begin{abstract}
ABSTRAK
Innovation is a necessity, because there is no stagnant life. Times keep changing, only people or institutions continue to innovate for surviving. While institutions which have no innovation are slow or fast, they are abandoned, stale, not marketable and do not keep up with the times. The innovation of pesantren-based schools is an effort to ensure that an institution continues to withstand the onslaught of modern era. Above destructive reality if not responded quickly, precisely, and intelligently will have more severe impact. In educational context, innovative ideas about pesantren-based schools and PAI learning innovation are one of the solutions which must be taken. Generally, PAI is as a nomenclature in schools, but it is not in Junior High School of Raudatut Tholabah, PAI learning developed at the school are AlQur'an - Hadith, Fiqh, SKI, and Aqidah Akhlak. The innovation of Islamic Learning Education Through Extracurricular Activities in SMP Raudatut Tholabah Jenggawah of Jember. It is the strengthening of religious values through the activities of having Dhuha Prayer and Dhuhur together, Reading and writing, tahfidzul and reading $\mathrm{Al}$ Qur'an together, Academic Guidance and Counseling Services, Scouting, Sports and the arts.
\end{abstract}

Kata Kunci: Inovasi PAI, Ekstrakurikuler

FENOMENA, Vol.18 No.1 April 2019 | 125 
Mursalim, Hatta

\section{PENDAHULUAN}

Pada umumnya mata pelajaran PAI merupakan nomenklatur di lembaga sekolah. Namun pada tataran realitas hal itu tidak terjadi, disekolah ada yang menerapkan pembelajaran PAI berupa mata pelajaran yang berdiri sendiri-sendiri, yakni : Al-Qur'an Hadits, SKI, Fiqih dan aqidah akhlak. Hal ini dilakukan sebagai inovasi pembelajaran PAI, karena PAI selama ini kurang atau bahkan tidak bisa menjawab problem laten kebutuhan zaman dan masyarakat. Perilaku immoralitas peserta didik kita semakin menghawatirkan.

Kehadiran sekolah-sekolah berbasis pesantren di berbagai daerah ditengarai oleh dua hal yang berkaitan erat, yaitu merosotnya moralitas anak bangsa dan kegagalan Pendidikan Agama Islam di pihak lain dalam melahirkan generasi yang memiliki budi pekerti luhur. Kemerosotan moral yang semakin parah dalam kehidupan berbangsa dan bernegara, terutama dalam konteks dunia pendidikan menengah merupakan fakta tidak terbantahkan.

Badan Kependudukan dan Keluarga Berencana Nasional (BKKBN) pusat merilis 64 juta remaja Indonesia rentan memiliki perilaku seks bebas dan pengguna zat tropika berbahaya. Dalam catatan BKKBN kelahiran penduduk usia remaja cenderung meningkat yakni 48/1000 kelahiran. Prosentase itu dapat menggambarkan para remaja sudah memiliki perilaku seks bebas. ${ }^{1}$ Di Daerah Istimewa Yogyakarta pada sepanjang tahun 2015, jumlah persalinan bayi oleh remaja berusia 10-18 tahun sangat tinggi. Berdasarkan data dari Perkumpulan Keluarga Berencana Indonesia (PKBI) Yogyakarta, 1.078 remaja puteri yang semestinya masih berstatus pelajar melahirkan bayi. Dari angka 1.078 remaja puteri yang melahirkan di 2015 tersebut, 976 diantaranya berasal dari kehamilan yang tak diinginkan. ${ }^{2}$ Di Jawa Timur, berdasarkan hasil pemetaan Kementerian Sosial, Menteri Sosial Khofifah Indar Parawansa menyatakan bahwa kasus kehamilan pelajar SMP dan SMA adalah yang tertinggi. Sebagai contoh di Pondok Pesantren Milenium Sidoarjo terdapat 252 anak dan di Pondok Pesantren Metal

1 https://m.tempo.co/read/news/2013/05/11/173479516/64-juta-remaja-galaurentan-seks-be-bas. Diakses pada 31 Maret 2017.

${ }^{2}$ http://www.pikiran-rakyat.com/pendidikan/2016/01/26/358573/sebanyak-976pelajar-yogya karta-hamil-di-luar-nikah. Diakses pada 31 Maret 2017. 
Pasuruan terdapat 106 anak. Ke 358 anak tersebut berasal dari kehamilan dan kelahiran yang tidak diinginkan. ${ }^{3}$

Kasus penyalahgunaan narkoba di kalangan pelajar di Indonesia juga sangat memprihatinkan. Menurut Badan Narkotika Nasional (BNN) di DKI Jakarta saja, dari 480.000 pelajar pada tahun 2014, sejumlah 22 persennya adalah pengguna aktif zat berbahaya tersebut. ${ }^{4}$ Kepala BNN Kota Kendari, Sulawesi Tenggara menjelaskan bahwa pengguna narkoba di kota itu selama 2016 didominasi oleh kalangan pelajar. Selama tahun 2016 sudah ditemukan 49 kasus narkoba. Sebanyak 36 kasus di antaranya adalah pelajar. ${ }^{5}$

Dari contoh-contoh kasus narkoba tersebut nampak jelas bahwa kalangan pelajar di lembaga-lembaga pendidikan merupakan salah satu target peredaran narkoba. Bahkan jauh dari perkiraan, lembaga pendidikan Islam seperti pesantren juga menjadi salah satu ekspansi sasaran jual beli narkoba. Menurut Badan Narkotika Provinsi (BNP) Jawa Barat,saat ini tidak ada kawasan lingkungan,termasuk lingkungan pendidikan pesentren yang steril dari peredaran narkoba.Dipilihnya pesantren sebagai target transaksi narkoba karena tempat ini dianggap aman, baik bagi pengedar maupun para pemakai. Selain menjadi target peredaran dan berlindung yang aman, jaringan pengedar mempunyai motif untuk menghancurkan institusi pesantren. ${ }^{6}$ Contoh faktual kasus penggunaan narkoba yang melibatkan para santri pondok pesantren terjadi di Kabupaten Blitar. Dewan Pimpinan Cabang (DPC) Granat Blitar melaporkan hasil pengungkapannya bahwa 10 santri di berbagai pesantren di Blitar positif menggunakan narkoba. ${ }^{7}$

Disamping pergaulan bebas dan narkoba, kasus lain yang menimpa kalangan pelajar adalah tawuran pelajar. Pada 11 Maret 2017 tawuran yang

\footnotetext{
${ }^{3}$ https://www.merdeka.com/peristiwa/jawa-timur-paling-tinggi-kasus-pelajar-hamildi-luarnikah.html Diakses pada 31 Maret 2017

${ }^{4}$ https://m.tempo.co/read/news/2014/08/20/064601070/bnn-22-persen-pelajar-danmahasiswa-pakai-narkoba Diakses pada 31 Maret 2017

${ }^{5}$ http://nasional.republika.co.id/berita/nasional/daerah/16/04/11/o5h9da336-gawatpelajar-mendominasi-penggunaan-narkoba Diakses pada 31 Maret 2017

${ }^{6} \mathrm{http} / / /$ wartaislam.com. bahaya! pesantren jadi target peredaran narkoba. Diakses pada 31 Maret 2017

${ }^{7}$ http://news.detik.com/berita-jawa-timur/798281/waspada-pondok-pesantrendiincar-bandar-narkoba. Diakses pada 31 Maret 2017
} 
melibatkan pelajar SMP di Kota Bekasi mengakibatkan satu orang pelajar meninggal dunia karena sabetan senjata tajam celurit. ${ }^{8}$ Di Kampung Caringin Sukabumi, dua kelompok pelajar yang berjumlah 26 terlibat tawuran massal dan mengakibatkan dua pelajar SMP terluka serius akibat sabetan samurai dan kelewang pada 29 April 2017.9 Di Desa Demung Situbondo, seorang pelajar MTs juga meninggal dunia akibat ditusuk senjata tajam pada peristiwa tawuran pelajar yang terjadi pada 8 Maret 2017..$^{10}$

Semakin maraknya tindak kriminalitas pada usia pelajar mendatangkan banyak keprihatinan dan kritik dari berbagai pihak. Diantara kritik tersebut dialamatkan pada kegagalan sekolah atau madrasah dalam menyelenggarakan Pendidikan Agama Islam. Menurut Baedowi, sekolah belum dianggap berhasil membawakan perannya sebagai agen perubahan karakter. ${ }^{11}$

Beberapa pakar dan praktisi Pendidikan Islam menyampaikan keprihatinan sekaligus kritik mengapa Pendidikan Agama Islam belum mampu melahirkan output pendidikan sebagaimana yang diharapkan. Muhaimin menunjukkan sejumlah indikator kegagalan Pendidikan Agama Islam dalam menggarap sikap dan prilaku keberagamaan peserta didik serta membangun moral dan etika bangsa. ${ }^{12}$ Indikator-indikator tersebut adalah (1) membudayanya ketidakjujuran dan rasa tidak hormat anak kepada orang tua dan guru di kalangan anak-anak dan remaja; (2) semakin maraknya anak-anak dan remaja yang gemar melihat gambar-gambar porno dan/atau menonton film dan situs porno; (3) semakin maraknya pacaran yang melampaui batas-batas norma agama, dan bahkan ada di antaranya yang telah melakukan hubungan seksual sebelum menikah; (4) meningkatnya

\footnotetext{
${ }^{8}$ https://metro.tempo.co/read/news/2017/03/12/064855143/tawuran-pelajar-dibekasi-seorang-siswa-smp-tewas-dicelurit. Diakses pada 14 Juli 2017.

9 http://nasional.republika.co.id/berita/nasional/daerah/17/04/30/op7ax3330tawuran-pelajar-smp-dua-luka-samurai-dan-klewang-disita. Diakses pada 14 Juli 2017.

${ }^{10}$ https://news.detik.com/berita-jawa-timur/d-3441781/dua-kelompok-pelajar-disitubondo-terlibat-perkelahian-satu-tewas. Diakses pada 14 Juli 2017.

${ }^{11}$ Ahmad Baedowi, dkk., Potret Pendidikan Kita (Jakarta: Pustaka Alvabet, 2015) hal. 313.

12 Muhaimin, Pemikiran dan Aktualisasi Pengembangan Pendidikan Islam (Jakarta: Rajawali Pers, 2012) hal. 154.
} 
tindak kekerasan atau pertengkaran di kalangan remaja; (5) semakin maraknya anak-anak bermain play station sehingga lupa berdzikir kepada Allah SWT, lalai shalat tepat pada waktunya, serta tidak gemar membaca alQuran dan berdoa; (6) semakin maraknya penggunaan narkoba serta minuman alkohol di kalangan para remaja; (7) menurunnya semangat belajar, etos kerja, kedisiplinan, dan kecenderungan untuk memperoleh hidup yang mudah tanpa kerja keras; (8) menurunnya rasa tanggung jawab anak-anak dan remaja, baik terhadap diri, keluarga, lingkungan masyarakat, maupun bangsa dan negara; dan (9) membudayanya nilai materialisme di kalangan anak-anak dan remaja.

Sementara itu, Mulyasa menyebutkan berbagai persoalan menyangkut eksistensi Pendidikan Agama Islam: ${ }^{13}$ (1) Islam diajarkan lebih pada hafalan, padahal Islam penuh dengan nilai-nilai (values) yang harus dipraktekkan; (2) pendidikan agama lebih ditekankan pada hubungan formalitas antara hamba dan Tuhannya; (3) penalaran dan argumentasi berfikir untuk masalahmasalah keagamaan kurang mendapat perhatian; (4) penghayatan nilai-nilai agama kurang mendapat penekanan; (5) menatap lingkungan untuk kemudian memasukkan nilai Islam sangat kurang mendapat perhatian; (6) metode pembelajaran agama, khususnya yang berkaitan dengan nilai-nilai Islam kurang mendapat penggarapan; (7) ukuran keberhasilan pendidikan agama juga masih formalitas termasuk verbalistis; (8) pendidikan agama belum mampu menjadi landasan kemajuan dan kesuksesan untuk mata pelajaran lain; (9) pendidikan agama belum dijadikan fondasi pendidikan karakter peserta didik dalam perilaku keseharian.

Berbagai perilaku pelajar pada kasus-kasus di atas jika tidak diselesaikan dengan tepat, maka akan menimbulkan kerusakan-kerusakan yang lebih serius dan semakin menyebar. Menghadapi fenomena tersebut diperlukan jalan keluar yang baik dan segera dilakukan oleh berbagai pihak, baik di lingkungan keluarga, sekolah, dan masyarakat agar hal-hal negatif tersebut tidak dibiarkan berlarut-larut. ${ }^{14}$ Disamping menimbulkan kerusakan-

${ }^{13}$ E. Mulyasa, "Meningkatkan Kualitas Pendidikan Agama Islam" dalam Abdul Majid dan Dian Andayani, Pendidikan Agama Islam Berbasis Kompetensi: Konsep dan Implementasi Kurikulum 2004 (Bandung: PT. Remaja Rosdakarya, 2004) iv.

14 Tim Dosen PAI, Bunga Rampai Penelitian dalam Pendidikan Agama Islam (Yogyakarta: Deepublish, 2016)171. 
kerusakan, hal tersebut juga memunculkan keresahan bagi masyarakat secara universal. $^{15}$

Gagasan dan praksis sekolah berbasis pesantren merupakan ikhtiar rasional untuk menemukan jalan keluar dari persoalan-persoalan pelik dunia pendidikan. Menteri Pendidikan dan Kebudayaan saat ini, Muhadjir Effendy dalam kunjungannya ke SMK Syubbanul Wathon, di Magelang, Jawa Tengah pada 27 Januari 2017, memberikan apresiasi terhadap proses belajar-mengajar di sekolah kejuruan berbasis pesantren yang mengintegrasikan antara pendidikan karakter berbasis agama dan pendidikan umum. ${ }^{16}$ Sedangkan Menteri Pendidikan dan Kebudayaan pada era sebelumnya, Muhammad Nuh juga mengapresiasi keberhasilan pola pendidikan yang diselenggarakan oleh pesantren dan oleh karenanya pemerintah memasukkan tradisi pendidikan pesantren ke sekolah umum. ${ }^{17}$

Sekolah Menengah Pertama Plus Roudhatut Thalabah di Kemuningsari Jenggawah Jember, adalah salah satu dari sekolah yang melakukan inovasi pembelajaran PAI, disekolah ini PAI berupa mata pelajaran yang berdiri sendiri-sendiri, yakni : Al-Qur'an Hadits, SKI, Fiqih dan Aqidah Akhlak. Sebagai salah satu penyelenggara pendidikan yang berbasis pesantren, tentunya inovasi ini butuh manajemen pengelolaan yang tepat. Maka dari itu Sekolah Menengah Pertama Plus Roudhatut Thalabah menarik untuk diteliti bagaimana sekolah ini menyelenggarakan inovasiinovasi pendidikan ke dalam proses pembelajarannya.

\section{Metodologi Penelitian}

Pendekatan yang digunakan dalam penelitian ini adalah kualitatif deskriptif. Maksud pendekatan kualitatif adalah memahami fenomena tentang apa yang dialami oleh subyek penelitian, misalnya prilaku, persepsi,

${ }^{15}$ Rahmat, PAl Interdisipliner: Layanan Khusus CIBI, Kenakalan Remaja, Integrasi Imtaq dan Iptek, Pendidikan Anti Kekerasan dan Kurikulum Berbasis Karakter (Yogyakarta: Deepublish, 2016) 32.

${ }^{16}$ http://www.jpnn.com/news/mendikbud-puji-sekolah-berbasis-pesantren. Diakses pada 15 Juli 2017.

${ }^{17}$ http://www.republika.co.id/berita/pendidikan/berita/10/12/11/151762pendidikan-pesantren-dinilai-berhasil-bentuk-karakter. Diakses pada 15 Juli 2017. 
motivasi, tindakan, dan lainya secara holistik. ${ }^{18}$ Adapun maksud deskriptif adalah menguraikan sifat-sifat atau karakteristik suatu keadaan dalam bentuk kata-kata atau bahasa. ${ }^{19}$ Teknik pengumpulan data dalam penelitian ini menggunakan beberapa metode:

a. Observasi. Metode ini digunakan untuk mengobservasi obyek penelitian, situasi geografis, dan kegiatan-kegiatan akademis yang relevan dengan fokus penelitian ini di Sekolah Menengah Pertama Plus Rhaudhatut Thalabah Kemuningsari Jenggawah Jember.

b. Interview. Metode ini digunakan untuk memperoleh data tentang aspek historis penyelenggaraan sekolah berbasis pesantren, data tentang wujud integrasi budaya pesantren melalui mata pelajaran, data tentang wujud integrasi budaya pesantren melalui kegiatan ekstrakurikuler, dan data tentang wujud dan integrasi budaya pesantren melalui manajemen sekolah.

c. Dokumentasi. Metode ini digunakan untuk memperoleh data tentang pelaksanaan kegiatan integrasi budaya pesantren melalui mata pelajaran, data tentang pelaksanaan kegiatan integrasi budaya pesantren melalui kegiatan ekstrakurikuler, dan data tentang pelaksanaan integrasi budaya santri melalui manajemen sekolah.

\section{PEMBAHASAN}

Pembelajaran PAI melalui ekstrakurikuler adalah berbagai program kegiatan keagamaan yang diselenggarakan di luar jam pelajaran dalam rangka memberikan tambahan bagi peserta didik untuk dapat mengamalkan ajaran agama yang diperolehnya melalui kegiatan belajar dikelas serta untuk mendorong pembentukan pribadi peserta didik dan penanaman nilai-nilai agama dan akhlakul karimah peserta didik. Tujuannya adalah membentuk manusia yang terpelajar dan bertaqwa kepada Allah SWT. ${ }^{20}$

Hasil pendidikan dipandang bermutu jika mampu melahirkan keunggulan akademik dan ekstrakurikuler pada peseta didik yang dinyatakan

\footnotetext{
${ }^{18}$ Lexy J. Moleong, Metode Penelitian Kualitatif (Bandung: Rineka Cipta, 2008) hal. 6.

${ }^{19}$ Suprapto, Metode Riset (Jakarta: Rineka Cipta, 2003) hal. 57.

1 Departemen Agama RI, Panduan Kegiatan Ekstrakurikuler Pendidikan Agama Islam, (Jakarta: Direktorat Jenderal Kelembagaan Agama Islam, 2005), 9.
} 
lulus untuk satu jenjang pendidikan atau menyelesaikan program pembelajaran tertentu. Keunggulan akademik dinyatakan dengan nilai yang dicapai oleh peserta didik. Keunggulan ekstrakurikuler dinyatakan dengan ketrampilan yang diperoleh siswa selama mengikuti program ekstrakurikuler keagamaan. Di luar kerangka itu, mutu luaran juga dapat dilihat dari nilainilai hidup yang dianut, moralitas, dorongan untuk maju dan lain-lain yang diperoleh peserta didik selama menjalani pendidikan. ${ }^{21}$

Pelaksanaan program ekstrakurikuler keagamaan di dilaksanakan rutin setiap hari dan disesuaikan dengan jadwal kegiatan itu sendiri dengan tersetruktur. Program ekstrakurikuler keagamaan rutinan setiap hari ini wajib dilaksanakan oleh seluruh warga madrasah, mulai dari siswa-siswi, para guru dan staf karyawan serta kepala sekolah. Tanggung jawab atas program ekstrakurikuler keagamaan di menjadi tanggung jawab bersama, untuk seluruh warga madrasah bukan hanya tanggung jawab kepala sekolah dan guru PAI saja, untuk guru pada disiplin ilmu yang lain ikut pula berpartisipasi dalam pelaksanaan program ekstrakurikuler keagamaan untuk mendidik, mengarahkan, serta membimbing para siswanya.

Mutamakin Abdullah, Kepala Sekolah program ekstrakurikuler keagamaan ini bertujuan untuk mewujudkan tujuan pendidikan islam yakni membentuk insan kamil. Yang paling utama adalah membentuk karakter seluruh warga madrasah untuk berakhlak mulia melalui pembiasaan program ekstrakurikuler keagamaan tersebut. ${ }^{22}$

Muhammad Yasin selaku guru agama menambahkan pula bahwasanya program ekstrakurikuler keagamaan ini dilaksanakan dengan harapan dapat membentuk nuansa yang religi pada madrasah serta membudayakan dan membiasakan para siswa dalam pengamalan ibadahnya yang tidak hanya sekedar teori tapi diwujudkan dengan pengamalan ibadah secara nyata, bertujuan pula membentuk karakter siswa yang religius, tanggung jawab, mandiri dan kejujuran. Pendidikan agama tidak hanya sekedar teori saja

${ }^{21}$ Rahmat Mulyana, Mengartikulasi Pendidikan Nilai, (Bandung: Alfabeta, 2004), 215217.

${ }^{22}$ Mutamakin Abdullah, Kepala SMP Raudatut Tholabah, Wawancara 24 September 2018 
Inovasi Pembelajaran PAI Melalui Kegiatan Ekstrakurikuler...

namun ada wujud pengamalan yang nyata. ${ }^{23}$

Program ekstrakurikuler keagamaan rutin ini pelaksanaanya dijadwalkan secara rapi dan testruktur. Sesuai hasil data yang diperoleh peneliti, maka dapat dianalisa sebagai berikut:

\section{Doa Bersama dan Membaca Al-qur'an}

Sebelum proses kegiatan belajar mengajar dimulai didalam kelas, seluruh pendidik dan tenaga kependidikan mengadakan doa bersama dan membaca al-Qur'an setiap pagi bertempat di musholla, yang dipimpin oleh seorang siswa yang bertugas mewakili kelasnya sesuai dengan jadwal. Hal ini diharapkan agar siswa terbiasa mengawali harinya untuk berbagai kegiatan apapun dengan berdoa mengharap ridho Allah SWT. Kemudian dilanjutkan membaca al-Qur'an yaitu surat Yasin secara bersama agar siswa dapat mengaplikasikan cara membaca al-Qur'an yang baik dan benar, selain itu juga membiasakan siswa membaca al-Qur'an baik dilingkungan sekolah maupun dilingkungan keluarga.

Membaca al-Qur'an merupakan bentuk peribadatan yang diyakini dapat mendekatkan diri kepada Allah SWT. dapat meningkatkan keimanan dan ketaqwaan yang berimplikasi pada sikap dan perilaku yang positif, dapat mengontrol diri, mendapat ketenangan, lisan terjaga dan istiqomah dalam beribadah. Melalui kegiatan membaca al-Qur'an para siswa dapat tumbuh sikap-sikap luhur sehingga berpengaruh terhadap peningkatan prestasi belajar dan juga dapat membentangi diri dari pengaruh negative. ${ }^{24}$

Hal tersebut diperkuat pernyataan bapak mutamakin abdullah : Motivasi membaca al-Qur'an atau khususnya surat yasin ini karena alQur'an tidak lain sebagai pedoman hidup bagi manusia, apabila seorang hamba membaca ayat al-qur'an akan mendapatkan pahala yang banyak dimana satu huruf diberi balasan dengan sepuluh kebajikan. Membaca surat yasin rutin setiap harinya akan memberikan manfaat yakni diberikan jalan

${ }^{23}$ Muhammad Yasin, Guru Qur'an Hadist SMP Raudatut Tholabah, Wawancara 24 September 2018

${ }^{24}$ Asmaun Sahlan, Mewujudkan Budaya Religius di Sekolah (Upaya Mengembangkan PAl dari Teori ke Aksi), (Malang: UIN-Maliki Press, 2009), 120. 
Mursalim, Hatta

kemudahan, petunjuk dan senantiasa ingat kepada Allah SWT. ${ }^{25}$

Untuk setiap hari jum'at doa bersama dan membaca al-Qur'an diganti dengan kegiatan istighosah dan lain-lain, istighosah adalah doa bersama yang bertujuan memohon pertolongan Allah SWT. inti dari kegiatan istighosah ini sebenarnya dzikrullah dalam rangka taqqaub ila Allah (mendekatkan diri kepada Allah SWT) serta untuk memperkaya dan menambah wawasan pengetahuan agama siswa melalui amalan-amalan sunnah yang dapat menambah tabungan amal kebaikan, karena amalanamalan sunnah merupakan anjuran untuk dikerjakan dan merupakan amalan yang baik yang dapat menghapus amalan yang buruk pada seseorang manusia, disebabkan manusia tidaklah luput dari tindakan salah. Selanjutnya amalan sunnah juga menyempurnakan kekurangan pada ibadah wajib yang mungkin terlewatkan oleh manusia. Jika manusia sebagai hamba selalu dekat dengan sang Khaliq, maka segala keingginannya akan dikabulkan oleh-Nya. Istighosah ini sudah membudaya di, hal ini karena memberikan pengaruh luar biasa pada mentalitas warga madrasah. ${ }^{26}$

Para siswa rutin menjalani kegiatan ini setiap harinya, termotivasi akan betapa besar manfaat yang dapat diperoleh dari kegiatan membaca AlQur'an tersebut. Hal ini menjadi penyemangat pada diri mereka ketika hendak menjalankan tugas mereka untuk menuntut ilmu. Kegiatan ini merupakan bagian dari bentuk program ekstrakurikuler tilawah dan tahsin Al-Qur'an dengan maksud tilawah dan tahsin al-Qur'an disini adalah kegiatan atau program pelatihan baca al-Qur'an dengan menekankan pada metode baca yang benar, dan kefasihan bacaan, serta keindahan (kemerduan) bacaan. ${ }^{27}$

\section{Sholat Dhuha Berjama'ah}

Sholat dhuha adalah shalat sunah yang dilakukan setelah terbit matahari sampai menjelang masuk waktu zhuhur. Afdhalnya dilakukan pada pagi hari

\footnotetext{
${ }^{25}$ Mutamakin Abdullah, kepala SMP Raudatut Tholabah. Wawancara pada tanggal 27 September 2018

${ }^{26}$ Mutamakin Abdullah, kepala SMP Raudatut Tholabah. Wawancara pada tanggal 27 September 2018

${ }^{27}$ Departemen Agama RI, Panduan Kegiatan Ekstrakurikuler Pendidikan Agama Islam, ibid., h. 13.
} 
disaat matahari sedang naik ( kira-kira jam 9.00 ). Sholat dhuha merupakan sholat sunnah, sholat yang apabila di kerjakan mendapatkan pahala dan apabila tidak di kerjakan tidak mendapatkan dosa

Pelaksanaan sholat dhuha di sekolah ini dijadikan sebagai program ekstrakurikuler keagamaan yang wajib diikuti oleh seluruhwarga madrasah dilaksanakan setelah membaca do'a dan al-Qur'an secara berjama'ah. Dilaksanakan pada jam 06.45 sebelum kegiatan belajar mengajar berlangsung. Hal itu sejalan dengan keingin bapak mutamakin abdullah yang ingin melihat semua warga sekolah ini berperilaku agamis sesuai dengan norma-norma ajaran agama terlebih bagi siswa, untuk itu saya tekankan kepada seluruh siswa wajib untuk mengikuti kegiatan pelaksanaan shalat Dhuha berjamaah, setiap hari di sekolah ini.karena itu Shalat Dhuha berjamaah sangat perlu dilakukan di sekolah baik siswa maupun guru. ${ }^{28}$

Adapun bilangan rakaat sholat dhuha sekurang-kurangnya adalah 2 rakaat dan sebanyak-banyaknya tidak ada batasan. Inilah yang dirajihkan oleh Syekh Ibnu Utsaimin dalam pernyataan beliau, Yang benar adalah bahwasanya tidak ada batas untuk banyaknya, karena 'Aisyah berkata: Rasulullah shallallahu 'alaihi wa sallam dahulu melakukan shalat dhuha sebanyak empat rakaat, dan beliau menambahnya sebanyak yang beliau inginkan. ${ }^{29}$

Jumlah rakaat shalat dhuha tidak ada pembatasannya. Seandainya seorang sholat dari terbit matahari setombak sampai menjelang tergelincir matahari, misalnya empat puluh rakaat, maka ini semua masuk dalam shalat dhuha. Pelaksanaan program ekstrakurikuler keagamaan sholat dhuha di dikerjakan rutin setiap harinya 4 rakaat dan mengucapkan salam setiap 2 rakaat, karena pada rakaat sholat dhuha tidak ada batasannya mengambil inisiatif untuk mengerjakan 4 rakaat berkenaan dengan waktu proses pembelajaran dikelas yang dilaksanakan setelah mengerjakan sholat dhuha.

Bacaan surat shalat dhuha Tidak ada keterangan dari Rasulullah mengenai surat tertentu yang harus dibaca ketika shalat dhuha. Kita dipersilahkan membaca surat apa pun sesuai dengan kemampuan dan

\footnotetext{
${ }^{28}$ Mutamakin Abdullah, kepala SMP Raudatut Tholabah. Wawancara pada tanggal 27 September 2018

${ }^{29}$ HR. Muslim, Kitab Shalat al-Musafirin wa Qashruha, Bab Istihbaab Shalat Dhuha, No. 719
} 
keinginan kita. Kita pun diperkenankan untuk membaca surat Adh-Dhuha, Asy-Syams, atau surat-surat lain yang menjadi favorit atau pilihan Di ada anjuran bacaan surat yang wajib dihafal untuk dibaca ketika melaksanakan sholat dhuha yaitu surat Asy-Syam dan Adh-Dhuha.

Tidak salah jika kita membaca surat Adh-Dhuha di dalam salah satu rakaat shalat dhuha. Sebab, banyak nilai-nilai moral dan spiritual yang terkandung di dalamnya. Harapanya, kita dapat memahami dan menghayatinya. Lalu, menjadikanya bekal untuk memulai aktivitas. Namun pada pelaksanaannya secara pribadi tidak mewajibkan untuk membaca kedua surat tadi para siswa bebas membaca surat yang dihafalnya atau yang disukainya.

Beberapa doa yang dibaca setelah sholat dhuha yaitu sholawat nariyah, sholawat tibh al qulub dan sholawat fatih. Dengan membaca sholawat nariyah bertujuan untuk Terlepas dari segala kesulitan (dimudahkan rezekinya), terhindar dari bencana, semua keinginan dikabulkan, kebutuhan bisa terpenuhi dan lain-lain. Shalawat tibh al qulub ini bila diamalkan secara istiqomah (ajeg, terus menerus) insyaAllah akan diselamatkan dari berbagai macam penyakit, baik penyakit lahiriah maupun batiniah. Tentu saja disamping itu juga terdapat manfaat-manfaat yang lain, sebagaimana keterangan dari banyak hadist Nabi SAW yang menerangkan keutamaan dari membaca shalawat akan memberikan berbagai macam kebaikan \& manfaat. Selanjutnya adalah sholawat fatih, Sholawat ini dikarang oleh Syech Sayyid Muhammad Syamsuddin ibn Abil Hasan al Bakri RA, adapun gunanya adalah: Untuk menghilangkan pikiran yang resah atau susah. Barang siapa membaca sholawat al Fatih tersebut, seumur hidup sekali saja Insya Allah diselamatkan dari api neraka. Sholawat nariyah, sholawat tibh al qulub dan sholawat fatih dijadikan sebagai doa setelah sholat dhuha dengan motivasi agar dalam menempuh pendidikan dimudahkan oleh Allah SWT.

Hal ini bertujuan untuk membentuk moral/akhlak seluruh warga madrasah khususnya para siswanya dengan baik, menginggat karena begitu besar manfaatnya bagi pribadi hamba yang menjalankan sholat dhuha ini. Beberapa manfaat yang diharapkan dapat membentuk moralitas bagi siswa yaitu: 
a. Sholat dhuha dapat meningkatkan kecerdasan fisikal, kecerdasan emosional spiritual dan kecerdasan intelektual. Untuk kecerdasan fisikal, sholat dhuha mampu meningkatkan kekebalan tubuh dan kebugaran fisik. Shalat dhuha merupakan alternative olahraga yang efektif dan efisien karena dilakukan pada pagi hari ketika sinar matahari pagi masih baik untuk kesehatan dan kondisi udara yang bersih. Penelitian mutakhir menjelaskan bahwa bukan olahraga berat dan mahal yang efektif untuk menjaga kebugaran tubuh. Namun, olahraga ringan dan tidak beresiko cedera serta dilakukan dengan senang hati yang terbukti mampu menjaga kebugaran tubuh. Di sini, SMP Raudatut Tholabah memilih shalat dhuha tentunya sebagai olahraga yang paling cocok. Untuk kecerdasan emosional spiritual, melaksanakan shalat dhuha pada pagi hari sebelum beraktivitas, selain berbekal optimisme, tawakal, serta pasrah atas segala ketentuan dan takdir Allah, dapat menghindarkan diri dari berkeluh-kesah dan kecewa karena kegagalan yang dialami. Untuk kecerdasan intelektual hal ini berkaitan sekali dengan pribadi siswa yakni memiliki tanggungjawab belajar, dengan sholat dhuha diharapkan proses belajar mengajar berjalan dengan baik, menjadikan pikiran lebih konsentrasi sehingga dimudahkan masuknya ilmu yang bermanfaat.

b. Sholat dhuha melancarkan rizki. Di SMP Raudatut Tholabah melalui sholat dhuha ini membentuk moral siswanya untuk senantiasa tidak melupakan doa dan bertawakal kepada Allah SWT. setelah usaha atau bekerja yang sungguh-sungguh. Kerja tanpa do'a adalah kesombongan dan "kekufuran" karena tidak "butuh" restu dan pertolongan dari sang maha pemilik rezeki. Do'a tanpa usaha adalah sia-sia atau omong kosong. Sedangkan tawakal adalah kepasrahan hati menerima segala ketentuan Allah satelah usaha dan do’a dilakukan. Jika berhasil, bersyukurlah. Tetapi, jika tidak berhasil, jangan bersedih dan putus asa. Yang harus dilakukan jika apa yang diinginkan tidak tercapai adalah mengevaluasi apa yang kurang dari usaha dan do'a kita. Salah satu hikmah diisyaratkanya shalat dhuha adalah jalan kemudahan usaha dan kelapangan rezeki yang diberikan Allah kepada hamba-Nya yang shaleh.

Menurut Muhammad Yasin, sholat dhuha berjama'ah ini bertujuan agar para siswa tidak hanya melaksanakan amalan/ibadah wajib saja namun 
mengajarkan dan membiasakan mengerjakan amalan-amalan sunnah. Hal ini bertujuan pula untuk mengharap rizqi dari Allah karena rizki tidak hanya berupa harta saja namun dalam berbagai aspek termasuk rizqi memperoleh ilmu pengetahuan yang barakah manfaat didunia dan akhirat. Hal ini merupakan pelatihan bentuk ibadah perorangan atau jama'ah yang bertujuan untuk menjadikan peserta didik sebagai muslim yang disamping berilmu juga mampu mengamalkan ajaran agamanya dalam kehidupan sehari-hari. ${ }^{30}$

Sholat dhuha ini dapat membentuk karakter moral yang baik bagi siswa yaitu tanggung jawab pribadi pada Tuhan terhadap amalan-amalan sunnah yang dilakukan. Menurut beberapa tanggapan dari para siswanya mereka sangat antusias dan dengan rutin melaksanakan sholat dhuha bukan hanya pada lingkungan sekolah namun pada kehidupan sehari-hari mereka diluar sekolah. pemahaman hikmah amalan tersebut dijadikan sebagai motivasi (targhib) untuk melaksanakan amanalan tersebut guna membangun diri menjadi lebih baik dan sebagai pendorong agar kita giat beribadah.

Adapun hasil dari program perencanaan budaya shalat dhuha berjamaah yang sudah dijalankan di SMP Roudhatut Thalabahini adalah sebagai berikut :

a. Setiap siswa wajib mengikuti shalat dhuha berjamah di sekolah

b. Bapak/ibu guru dan karyawan diharapkan ikut mendampingi, terutamabapak/ibu wali kelas masing - masing yang anak- anaknya sedang melaksanakan shalat berjamaah.

c. Pelaksanaan shalat dhuha berjamaah dilaksanakan masing-masing kelas sesuai dengan jadwal yang sudah ada. Sedang rencana pengembangan kedepan dalam membudayakan agama di sekolah ini adalah dengan melaksanakan khotmil Qur'an yang direncanakan setiap tiga bulan sekali.

Dalam membudayakan shalat dhuha berjamaah di SMP Roudhatut Thalabah berbasis Pesantren, kepala sekolah selalu memerikan keteladanan kepada guru, karyawan dan siswa. Misalnya, kepala sekolah selalu mempersiapkan diri lebih awal ke masjid sambil melihat-lihat suasana

${ }^{30}$ Muhammad Yasin, Guru Qur'an Hadist SMP Raudatut Tholabah, Wawancara 27 September 2018 
lingkungan di masjid sebelum bel istirahat, kemudian baru mengikuti shalat dhuha berjamaah. Ini sering dilakukan kepala sekolah jika beliau tidak ada tugas dinas diluar. Bahkan tidak hanya kegiatan shalat dhuha berjamaah saja, kegiatan lain seperti menyantuni anak-anak yatim yang ada di sekolah yang diadakan pada tahun baru islam, ini setiap tahun selalu beliau lakukan, beliau juga berpakian atau berbusana rapi yang selalu beliau contohkan didepan guru, karyawan dan para siswa. Hal ini sesuai dengan hasil observasi peneliti yang termasuk salah satu guru agama di SMP Roudhatut Thalabah. $^{31}$

\section{Sholat Dhuhur Berjama'ah}

Pembiasaan merupakan upaya yang sangat penting dilakukan dalam hal pembinaan dan pembentukan kepribadian seseorang. Kebiasaan adalah sebuah tindakan atau perbuatan seseorang yang dilakukan secara berulangulang dalam bentuk yang sama sehingga menjadi kebiasaan. Langkah selanjutnya yang dilakukan oleh SMP Raudatut Tholabah adalah membiasakan siswa untuk disiplin dalam melaksanakan sholat berjama’ah

Sholat dalam bahasa arab berarti Do'a, sedangkan yang di maksud sholat disini adalah ibadah yang tersusun dari beberapa perkataan dan perbuatan yang dimulai dengan takbir, dan di sudahi dengan salam. Sholat dhuhur dilaksanakan secara berjama'ah oleh seluruh warga madrasah agar tercipta kebersamaan dan kekeluargaan. Diketahui bahwasanya ibadah sholat lebih utama dilaksanakan secara berjama'ah dan pahala yang didapatkan juga lebih banyak dibandingkan dengan sholat sendiri.10

Menurut Mohammad Yasin Pelaksanaan sholat dhuhur berjama'ah ini setelah jam pelajaran 5-6 pada pukul 12.00. Ketika waktu dhuhur tiba bel istirahat dibunyikan dan jam pelajaran dihentikan. siswa segera di kondisikan ke masjid, agar waktu yang tersedia mencukupi untuk mengambil air wudlu dan shalat berjamaah ${ }^{32}$

Adapun pelaksanaannya sama seperti pada umumnya di masjid sekolah, ada yang betugas sebagai muadzin yakni dari siswanya sendiri. Pelaksanaan

\footnotetext{
${ }^{31}$ Observasi pada tanggal 27 September 2018

32 Mohammad Yasin, guru PAI SMP Raudatut Tholabah. Wawancara 24 September 2018
} 
sholat dhuhur ini juga terstruktur dengan baik hal ini dibuktikan dengan adanya jadwal untuk tiap kelas yang bertugas sebagai muadzin, hal ini bertujuan melatih ketrampilan, dan pengamalan ibadah para siswa-siswinya. Sedangkan yang bertugas sebagai imam adalah para guru atau staf karyawan yang telah terjadwal pula untuk guru-guru atau karyawan yang tidak mendapatkan tugas sebagai imam bertanggung jawab untuk mendampingi para peserta didik yang melaksanakan sholat dhuhur. ${ }^{33}$

Motivasi menjalankan sholat dhuhur berjamaah ini selain begitu besar manfaat dan terdapat hikmah lain yang menyangkut beberapa aspek, baik aspek pendidikan, sosial maupun dari sisi balasan yang akan kita dapatkan (pahala). Pada aspek pendidikan, kita ambil contoh shalat berjama'ah yang mengajarkan akan sikap kedisiplinan. Hal ini bisa dilihat dari adanya kedisiplinan waktu dalam melaksanakannya. Ketika adzan berkumandang, praktis para warga madrasah yang melakukan shalat berjamaah akan bergegas menuju masjid pada waktu itu juga. Disamping itu, shalat yang dilaksanakan secara berjamaah juga mendidik kita untuk menghilangkan sikap egoisme Sebab kita tidak mungkin mengikuti kemuauan kita untuk ruku' mendahului imam atau melakukan salam lebih dini. Akan tetapi kita dituntut taat mengikuti gerak gerik seorang imam.

Dengan demikian, semakin kita sering shalat berjamaah maka semakin terdidik diri kita untuk mengendalikan atau melunakan sikap egoisme pada diri kita. Dari aspek sosial, shalat berjama'ah merupakan manifestasi dari itihadul musim (bersatunya umat islam). Tanpa adanya pecah bela diantara mereka. Tanpa memandang derajat antara kaya dan miskin. Bersatu padu dalam komando seorang imam. Disamping itu, ibadah sholat yang di lakuan secara jama'ah akan mencipatankan rasa empati terhadap sesama, hingga akhirnya tercipta sebuah rasa kasih sayang antar sesama muslim yang berawal dari ta'aruf (saling mengenal). ${ }^{34}$

Sebagai gambaran nyata, masyarakat saat ini pada umumnya di sibukan dengan berbagai ativitas sehari-hari, akan tetapi dengan adanya sholat berjama'ah seperti sholat lima waktu ataupun shalat jumaat maka akan

\footnotetext{
${ }^{33}$ M. Yusuf, Waka Kesiswaan. Wawancara 27 September 2018

${ }^{34}$ Mutamakin Abdullah, kepala SMP Raudatut Tholabah. Wawancara 27 September
} 2018 
memberikan solusi untuk saling mengenal dan menjalin silaturrahmi menjadi dekat antar sesama warga madrasah baik hubungan guru dengan guru, hubungan siswa dengan siswa maupun hubungan guru dengan siswanya. Sedangkan balasan bagi mereka yang melakuan shalat berjama'ah ialah pahala yang berlipat ganda. Sebagaimana Sabda Rasulullah SAW: Shalat berjamaah lebih utama dua puluh tujuh derajat daripada shalat sendirian. $^{35}$

Hadits ini setidaknya memberikan motivasi kepada para warga madrasah untuk senantiasa berlomba-lomba dalam melaksanakan ibadah shalat secara berjama'ah. Alloh berfirman, Sesunggubnya orang-orang munafik itu menipu Allah, dan Allah akan membalas tipuan mereka. Dan apabila mereka berdiri untuk shalat mereka berdiri dengan malas. Mereka bermaksud riya (dengan shalat) di hadapan manusia. Dan tidaklah mereka menyebut Allah kecuali sedikit sekali.(QS. An-Nisa' 142).

Disiplin waktu adalah suatu hal yang sangat sulit diterapkan, apalagi jika berbicara tentang sholat. Kebiasan buruk yang ditimbulkan oleh siswa sangat memprihatinkan jika guru tidak mengambil langkah untuk memberbaiki kebiasaan itu.

Jika ditarik kesimpulan dari ungkapan diatas, maka disiplin dengan pembiasaan adalah suatu hal yang tidak dapat dipisahkan. Guru dituntut untuk mendidik siswa agar siswa disiplin dalam sholat dan mebiasakan untuk melaksanakan sholat berjama'ah. Disamping itu, disiplin pembiasaan sholat berjama'ah memberikan pesan moral yang sangat berpengaruh terhadap perubahan perilaku siswa. Siswa lebih bisa menghargai waktu dan saling menjalin silaturrahmi antar sesama.

\section{Membaca Asmaul Husna}

Asmaul Husna adalah nama-nama Allah SWT yang baik, Asmaul Husna merupakan cerminan dari perilaku Allah SWT terhadap umatnya. Karena itu bila nama-nama itu kita sebut sebagai suatu pemohonan, maka akan mempunyai pengaruh yang sangat besar.

Menurut M. Yusuf, asmaul Husna ini dibaca pada setiap hari kamis saja untuk lebih meningkatkan keimanan dan ketaqwaan para siswa. dan hal

\footnotetext{
${ }^{35}$ HR. Al-Bukhari no. 131 dan Muslim No. 650
} 
ini bertujuan mengarah pada kecakapan ubudiyah dan akhlakul karimah. Diharapkan pula para siswa-siswi dapat meneladani sikap-sikap seperti yang terkandung dalam asmaul husna. ${ }^{36}$

Dalam setiap asmaul husna mempunyai makna yang berbeda-beda, jika diamalkan secara rutin SMP Raudatut Tholabah mengharapkan semoga mendapatkan manfaat dari setiap pelafalan asmaul husna terhadap semua warga sekolahhnya berkenaan dengan segala aktivitas pembelajaran di sekolah dan berkelanjutan pada aktivitas sehari-hari pada setiap pribadi untuk mengamalkannya. Kesungguhan dalam mengamalkan Asmaul Husna merupakan syarat yang mutlak diterimanya suatu permohonan, selain itu dibutuhkan juga keyakinan dan kesabaran yang penuh.

Menurut Ahmad Wahyudi, pengaruh dari hasil istiqomah membaca asmaul husna merupakan tambahan pengetahuan yang bermanfaat bagi siswa-siswi disekolah dan mendapatkan pahala yang lebih dari amalan membaca asmaul husna tersebut. ${ }^{37}$

Dalam membudayakan nilai keagamaan diatas (membaca doa dan alQur'an, Shalat dhuha dan dhuhur berjamaah, serta membaca asmaul husna di sekolah ini tidak lepas dari dukungan dan peran serta guru, karyawan, para siswa serta kepala sekolah itu sendiri. Kepala sekolah mempunyai keinginan bahwa para siswa kedepan harus memiliki ahlak mulia dan berjiwa Islami serta dapat mengamalkan ajaran-ajaran Islam dengan benar, sehingga para siswa mengerti, memahami dan mampu mengamalkan nilainilai Islam yang ada, mesikipun mereka berada pada sekolah umum tapi berbasis Islam.

Oleh karena itu semua kebijakan kepala sekolah dalam hal ini kebijakan tentang shalat dhuha dan dhuhur berjamaah harus ada dukungan semua warga sekolah baik guru, karyawan maupun siswa. Oleh Karenanya untuk menggerakkan semua warga sekolah, kepala sekolah sebagai figur pokok harus ikut serta dan andil dalam kegiatan apapun terlebih kegiatan keagamaan, karena hal itu merupakan salah satu bentuk dukungan kepala sekolah terhadap program yang dijalankan.

Hal ini sesuai apa yang diungkapkan Bapak Mutamakin Abdullah

\footnotetext{
${ }^{36}$ M. Yusuf, Waka Kesiswaan. Wawancara 1 Oktober 2018

${ }^{37}$ Ahmad Wahyudi Ketua OSIS, wawancara 1 Oktober 2018
} 
selaku kepala sekolah dalam wawancara dengan peneliti, beliau mengungkapkan bahwa Berkembangnya pelaksanaan shalat Dhuha berjamaah di sekolah ini tidak lepas dari peran serta semua pihak, baik guru, karyawan, siswa, maupaun saya sendiri yang terus tidak henti hentinya memberikan motivasi bagi guru dan siswa. Memang sejak dulu saya berkeinginan agar anak-anak di sekolah ini harus memiliki ahlak dan berjiwa Islam serta dapat mengamalkan ajaran Islam sehingga mereka mengerti, memahami, dan mampu melaksanakan nilai-nilai Islam dengan benar. ${ }^{38}$

Oleh karena itu semua yang menjadi keinginan saya tersebut harus ada dukungan dari semua warga sekolah baik guru, karyawan dan siswa, kalau hanya mengandalkan kepala sekolah saja, tentu semua kegiatan tidak akan bejalan dengan baik. Karena itu saya harus andil ikut serta dalam semua kegiatan termasuk dalam melaksanakan shalat dhuha berjamaah di sekolah ini, hal ini merupakan salah satu dukungan saya terhadap program yang ada. ${ }^{39}$

Ketika peniliti melakukan observasi di sekolah kegiatan keagamaan yang bersifat rutinitas dilaksanakan setiap hari di sekolah adalah membaca doa dan al-Qur'an, shalat dhuha dan dhuhur berjamaah, yang pelaksanannya telah diatur sesuai dengan jadwal yang sudah ada. Dalam setiap kegiatan dalam program kerja harus ada evalusi untuk mengetahui tingkat keberhasilan dari program yang telah dilaksanakan, begitu pula di SMP Roudhatut Thalabah berbasis Pesantren. Dalam membudayakan shalat dhuha berjamaah di sekolah salah satu strategi yang dilakukan kepala sekolah adalah dengan melakukan evaluasi terhadap pelaksanaan kegiatan ekstrakulekuler yang telah menjadi program rutin sekolah.

Evaluasi tersebut dilaksanakan ketika ada rapat dinas sekolah maupun pada rapat pembinaan yang dilakukan setiap hari senin setelah upacara bendera dilaksanakan. Hal ini sesuai paparan yang di samapaikan oleh Bapak Mutamakin Abdullah, selaku kepala sekolah dalam wawancara dengan peneliti, beliau mengungkapkan bahwa untuk mengatahui tingkat keberhasilan pelaksanaan kegiatan shalat dhuha berjamaah di sekolah saya adakan evaluasi terhadap program yang telah dijalankan,baik pada saat rapat

\footnotetext{
${ }^{38}$ Mutamakin Abdullah, kepala SMP Raudatut Tholabah, Wawancara 1 Oktober 2018

${ }^{39}$ Mutamakin Abdullah, kepala SMP Raudatut Tholabah, Wawancara 1 Oktober 2018
} 
dinas sekolah atau pada saat rapat pembinaan yang saya lakukan setiap hari senin setelah upacara bendera selesai. ${ }^{40}$

Apa yang telah disampaikan kepala sekolah tersebut, menandai bahwa semua kegiatan selalu di evaluasi, bahkan menurut peneliti evaluasiyang dilakukan oleh kepala sekolah tidak hanya pada saat rapat dinas sekolah atau setelah upacara bendera saja, tapi juga dilakukan melalui koordinasi dan konsultasi secara lansung terhadap guru maupun guru agama sebagai pelaksananya. Dari hasil koordinasi itu muncul pernyataan dari kepala sekolah sebagai berikut Saya sangat berharap kepada bapak/ibu guru semuanya untuk selalu memantau dan ikut serta dalam kegiatan rutinitas shalat dhuha berjamaah di sekolah ini, bahkan bapak/ibu guru juga selalu mengingatkan pada anak-anak untuk selalu aktif mengikuti shalat dhuha dan dhuhur berjamaah termasuk para wali kelasnya. ${ }^{41}$

Seperti yang dijelasakan diatas, bentuk strategi kepala sekolah dalam membudayakan kegiatan shalat dhuha berjamaah disekolah dengan mengadakan evaluasi, dan evaluasi terdiri dari evaluasi terstruktur dan kondisional. Evaluasi kondisional dilakukan kepala sekolah secara lansung kepada guru ketika bertemu diligkungan sekolah. Hal ini diungkapkan kepala sekolah pada peneliti ketika peneliti menayakan, bagaimana cara Bapak kepala sekolah dalam melakukan evaluasi secara kondisinal ? Beliau menjawab; Selain evaluasi yang kita lakukan setiap rapat dinas atau setelah selesai upacara bendera (rapat pembinaan), sering saya melakukan evaluasi secara kondisional terhadap pelaksanaan shalat dhuha berjamaah di sekolah ini, misalnya saya sering berkeliling memantau kegiatan KBM di sekolah ini, saya bertemu dengan bapak/ibu guru saya ajak berbicara tentang pelaksanaan shalat dhuha berjamah yang sudah berjalan ini, saya butuh masukan dan saran sebagai bahan evaluasi kegiatan tersebut. Begitu juga ketika saya berada diruang TU saya juga menyakan kepada salah satu karyawan yang ada, tentang bagiamana pelaksanaan shalat dhuha bejamaah di sekolah ini, termasuk ahlak anak-anak, sehingga saya mengetahui tingkat keberhasilan apa yang menjadi harapan yang saya ingin menjadikan kedepan

\footnotetext{
${ }^{40}$ Mutamakin Abdullah, kepala sekolah, Wawancara pada tanggal 1 Oktober 2018

${ }^{41}$ Mutamakin Abdullah, kepala sekolah, Wawancara pada tanggal 1 Oktober 2018
} 
sekolah ini memiliki siswa yang berahlak mulia. ${ }^{42}$

Adanya evaluasi terhadap pelaksanaan kegiatan ekstrakurikuler juga dibenarkan oleh Bapak Badri bahwa dalam melaksanakan program kerja yang telah disepakati bersama untuk dijalankan seperti halnya membudayakan shalat dhuha berjamaah di sekolah, dan untuk mengetahui keberhasilan kepala sekolah dalam ikut membudayakan shalat dhuha berjamaah di lingkungan sekolah ini juga diadakan evaluasi program kegiatan, dan banyak hal lain yang kepala sekolah tekankan termasuk pada kegiatan program kerja guru. Ketika dalam wawancara beliau mengatakan bahwa; Dalam melaksanakan program kegiatan telah disepakati bersama untuk dijalankan seperti halnya membudayakan shalat dhuha berjamaah di sekolah ini, saya tahu bahwa untuk mengetahui keberhasilannya kepala sekolah selalu mengevaluasi, ya biasanya melalui rapat dinas, rapat pembinaan yang dilaksanakan setiap hari senin setelah upacara bendera, juga serin kali ketika bertemu diruang guru atau ketemu dimana saja ketika melihat guru yang lagi tidak ngajar didalam kelas beliau mengajak komunikasi, dalam pembicaraan tersebut sering kali kepala sekolah dengan nada santai mengevaluasi program belajar mengajar dikelas, juga disinggung pengembangan budaya agama di sekolah ini terutama tentang pelaksanaan shalat dhuha berjamaah dan banyak hal lain yang beliau singgung terhadap kegiatan dan program sekolah kedepan. ${ }^{43}$

Evaluasi yang dilakukan kepala sekolah secara kondisional tidak hanya dilakukan diruang kantor maupun ketika bertemu dengan guru pada jam kosong. Evaluasi juga sering dilakukan diluar tugas dinas dalam keadaan santai, pada saat peneliti hadir untuk melakukan wawancara dengan salah seorang guru tiba-tiba kepala sekolah memanggil saya dan mengajak bicara dengan santai bersama waka kesiswaan,waka sapras dan waka kurikulum tentang perkembangan sekolah kedepan, mulai dari kondisi guru, mutu sekolah dan juga disinggung tentang kegiatan keagamaan secara umum.

Dalam kesempatan itu juga kepala sekolah dengan waka kesiswaan, Waka sapras, Waka kurikulum diruang guru dengan kondisi santai mengajak ngobrol dan secara langsung menurut pengamatan peneliti, kepala

\footnotetext{
${ }^{42}$ Mutamakin Abdullah, kepala SMP Raudatut Tholabah, Wawancara 1 Oktober 2018

${ }^{43}$ Mutamakin Abdullah, kepala SMP Raudatut Tholabah, Wawancara 1 Oktober 2018
} 
sekolah langsung mengungkapkan hal sebagai berikut; Bagaimana perkembangan sekolah kita kedepan? dan bagaimana anak-anak sudah terfasilitasi secara maksimal, apakah ada sarana prasara yang perlu di lengkapi, tanya kepala sekolah pada waka sapras. Sedangkan kepada waka kesiswaan bertanya tentang ahlak dan perilaku anak-anak apakah sudah mematuhi peraturan dan tata tertib di sekolah ini?, tentang kegiatan anakanak dalam pelaksanaan kegiatan ekstarakulekuler (keagamaan) yang dilakukan secara rutin di sekolah ini? Hal tersebut dijawab oleh masing masing wakil kepala sekolah dengan jawaban yang jelas, dan selanjutnya kepala sekolah memberikan masukan untuk tetap dijalankan program yang telah disepakati bersama, agar kedepannya kegiatan menjadi lebih baik dari hari ini dan hari sebelumnya. ${ }^{44}$

Dari hasil beberapa wawancara serta observasi yang peneliti lakukan, dapat diambil suatu kesimpulan bahwa dalam mengembangkan budaya agama di sekolah terutama pelaksanaan shalat dhuha berjamaah, strategi yang dilakukan kepala sekolah adalah dengan cara ikut andil dan ikut serta mendukung dalam setiap kegiatan shalat dhuha berjamaah, memberikan keteladanan kepada warga sekolah dan melakukan evaluasi terhadap program kegiatan yang telah dijalankan. Evaluasi yang dijalankan kepala sekolah terdiri dari evaluasi terstruktur dan kondisional.

\section{KESIMPULAN}

Secara sosiologis, kehadiran sekolah-sekolah berbasis pesantren tidak lepas dari beberapa hal, yaitu anggapan bahwa pendidikan Agama Islam dewasa ini belum berhasil -untuk tidak mengatakan gagal- dalam membentuk prilaku peserta didik yang sesuai dengan ajaran normatif agama Islam. Fakta memprihatinkan dan mencemaskan di lapangan memang tidak bisa dibantah. Kasus yang melibatkan pelajar, khususnya siswa sekolah menengah dalam pergaulan bebas, narkoba, minuman keras, perkelahian massal, dan tindak kriminal lainnya hampir setiap hari diberitakan. Hal lainnya yang menyebabkan lahirnya sekolah-sekolah berbasis pesantren adalah fenomena umum kemerosotan moral di berbagai elemen masyarakat. Kasus-kasus korupsi yang semakin sulit diberantas, perusakan lingkungan

\footnotetext{
${ }^{44}$ Mutamakin Abdullah kepala SMP Raudatut Tholabah, Wawancara 1 Oktober 2018
} 
hidup, ketidakadilan sistem peradilan, suap-menyuap, perdagagan narkoba yang semakin massif, dan lain-lain sebagainya adalah peristiwa luar biasa yang seolah dianggap biasa.

Realitas destruktif di atas jika saja tidak direspon dengan cepat, tepat, dan cerdas maka akan menimbulkan dampak kerusakan yang lebih parah. Dalam konteks pendidikan, munculnya gagasan inovatif tentang sekolah berbasis pesantren serta inovasi pembelajaran PAI merupakan salah satu solusi yang harus diambil. PAI yang umumnya sebagai nomenklatur disekolah, namum tidak terjadi di Sekolah Menengah Pertama Raudatut Tholabah, pembelajaran PAI yang dikembangkan disekolah tersebut. berbentuk Al-Qur'an- Hadits, Fiqih, SKI, dan Aqidah Akhlak.

Inovasi Pembelajaran Pendidikan Agama Islam Melalui Kegiatan Ektrakurikuler di SMP Raudatut Tholabah Jenggawah Jember, adalah penguatan nilai-nilai keagaman melalui kegiatan Sholat Dhuha dan Dhuhur berjamaah, Baca tulis, tahfidzul dan Tadarus Al Qur'an, Layanan Bimbingan dan Konseling akademis, Kepramukaan, Olahraga dan kesenian.

\section{DAFTAR PUSTAKA}

Ahmad Baedowi, dkk., Potret Pendidikan Kita (Jakarta: Pustaka Alvabet, 2015)

Abdul Majid dan Dian Andayani, Pendidikan Agama Islam Berbasis Kompetensi: Konsep dan Implementasi Kurikulum 2004 (Bandung: PT. Remaja Rosdakarya, 2004)

Dedi Mulyana, Metodologi Penelitian Kualitatif (Bandung: Remaja Rosdakarya, 2006)

Gugunel-Guyanie, Resolusi Jihad Paling Syari (Yogjakarta: Pustaka Pesantren, 2010)

Haidar Putra Daulay, Pendidikan Islam, dalam Sistem Pendidikan Nasional Indonesia, Jakarta: Kencana, 2004.

Haidar Putra Daulay, Historisitas dan Eksistensi Pesantren dan Madrasah, (Yogyakarta: Tiara Wacana, 2001)

Kementerian Pendidikan dan Kebudayaan RI, Direktorat Jenderal Pendidikan Dasar dan Menengah, Direktorat Pembinaan SMP, 
Mursalim, Hatta

Laporan Monitoring dan EvaluasiProgram Sekolah Berbasis Pesantren (Jakarta: KEMENDIKDASMEN, 2016)

Koentjaraningrat, Kebudayaan, Mentalitet dan Pembangunan (Jakarta: Gramedia, 1976.

Lexy J. Moleong, Metode Penelitian Kualitatif (Bandung: Rineka Cipta, 2008)

M. Syaifuddien zuhriy budaya pesantren dan pendidikan karakter Pada pondok pesantren salaf, Jurnal Walisongo,UIN SUKA Yogyakarta Volume 19, Nomor 2, November 2011

Mastuhu, Sistem Pendidikan pesantren, INIS, Jakarta, 1994

Muhaimin, Pemikiran dan Aktualisasi Pengembangan Pendidikan Islam (Jakarta: Rajawali Pers, 2012)

NurcholisMadjid,Bilik bilikPesantren(Jakarta:Paramadina,1997)

Rahmat, PAI Interdisipliner: Layanan Khusus CIBI, Kenakalan Remaja, Integrasi Imtaq dan Iptek, Pendidikan Anti Kekerasan dan Kurikulum Berbasis Karakter (Yogyakarta: Deepublish, 2016)

Said Aqil Siroj, Tasawuf sebagai Kritik Sosial: Mengedepankan Islam sebagai Inspirasi bukan Aspirasi (Bandung: Mizan, 2006)

Sudarwan Danim, Menjadi Peneliti Kualitatif (Bandung: Pustaka Setia, 2002)

Sudarwan Danim, Menjadi Peneliti Kualitatif, hal. 209-210.

Sugiyono, Metode Penelitian Kuantitatif Kualitatif (Bandung: Alfabeta, 2010)

Suprapto, Metode Riset (Jakarta: Rineka Cipta, 2003)

Tim Departemen Agama RI, Pola Pengemabangan Pondok Pesantren (Jakarta: Direktorat Jenderal Kelembagaan Agama Islam, 2003)

Tim Dosen PAI, Bunga Rampai Penelitian dalam Pendidikan Agama Islam (Yogyakarta: Deepublish, 2016)

Zamakhsyari Dhofier, Tradisi Pesantren Studi Tentang Pandangan Hidup Kiyai(Jakarta: LP3ES, 1981). 